\title{
Mapping in Intellectual Capital Measurement in Creative Industries in East Java
}

\author{
Gendut Sukarno ${ }^{1}$, Wulan Retno Wigati ${ }^{2}$, Sulastri Irbayuni ${ }^{1} \&$ Mas Anienda Tien Fitriyah ${ }^{3}$ \\ ${ }^{1}$ Program Studi Manajemen Universitas Pembangunan Nasional "Veteran” Jawa Timur, Surabaya, Indonesia \\ ${ }^{2}$ UPT Pusat Bahasa dan Urusan Internasional Universitas Pembangunan Nasional "Veteran” Jawa Timur, Surabaya, \\ Indonesia \\ ${ }^{3}$ Fakultas Hukum Universitas Pembangunan Nasional "Veteran” Jawa Timur, Surabaya, Indonesia \\ Correspondence: Gendut Sukarno, Program Studi Manajemen Universitas Pembangunan Nasional "Veteran" Jawa \\ Timur, Surabaya, Indonesia.
}

Received: April 30, 2019

Accepted: May 30, 2019

Online Published: June 10, 2019

doi:10.5430/ijfr.v10n5p145

URL: https://doi.org/10.5430/ijfr.v10n5p145

\begin{abstract}
In the context of global competition, competition not only occurs in the world of industry and trade, but also applies to creative businesses or more specifically creative industries which are industries that come from the utilization of individual skills, creativity and talent in creating welfare and employment use. Problems in managing SMEs and creative industries that have not been resolved are intellectual capital issues.

One approach used in the assessment and measurement of knowledge assets (intellectual property / assets) is Intellectual Capital which consists of 3 main elements, namely Human Capital, Structural Capital, and Relational Capital. Creative industries are industries that are unique and emphasize creativity, innovation and utilization of individual talents need to get maximum management. The purpose of this study is to find a model, the appropriate components of intellectual capital, and to get a real picture of the rules of Human Capital; Structural Capital and Relational Capital for creative industries in East Java. The sample in this study is the owner / manager / leader of 5 creative industry sub-sectors in 9 cities in East Java (Surabaya, Pasuruan, Probolinggo, Mojokerto, Batu, Malang, Kediri, Blitar, and Madiun) with a sample of 45 as respondents. The analysis technique used in this study is the Spider Plot Diagram.

Based on the results of the survey and studies, the aspect of mapping of intellectual capital in 5 (five) creative industry sub-sectors in East Java shows that relational capital is more dominant followed by human capital, and the lowest is structural capital.
\end{abstract}

Keywords: intellectual capital, human capital, structural capital, relational capital, spider plots, creative industries

\section{Introduction}

The presence of competition in the ASEAN Economic Community (MEA) is difficult to avoid. Indonesia must start preparing itself if Indonesia does not wish to be an easy target for the entry of products from ASEAN member countries into the country. The era of the ASEAN Economic Community (AEC) which began in 2015 brings an opportunity as well as a challenge for the Indonesian economy. With the enactment of the AEC at the end of 2015, ASEAN member countries will experience a free flow of goods, services, investment and educated labor from and to each country.

Through MEA there will be an integration in the form of "free trade area" (free trade area), the elimination of trade tariffs between ASEAN countries, as well as the free labor market and capital market, will greatly affect the economic growth and development of each country. To face the free market era in Southeast Asia, businesses must take strategic steps in order to face competition from other ASEAN countries, including the creative industry sector (Ahmed, Khalid, Ammar \& Shah, 2017).

In this regard, the Government has issued Presidential Instruction Number 6 of 2009 concerning the Development of Creative Economy as a basis for all stakeholders in developing 14 creative economic sectors. The creative industry sub-sectors: Advertising, Architecture, Art and Antiques Market, Crafts, Design, Fashion, Video-Film and 
Photography, Interactive Games, Music, Performing Arts, Publishing and Printing, Computer and Software, Television and Radio, Research and Development. The creative industry that has been proclaimed by the Ministry of Tourism and Creative Economy which consists of 14 fields, Fashion and Crafts is the dominant sub-sector in making economic contributions. Both types of industries have become locomotives in the development of the national creative industry. "The contribution of fashion and craft far outperforms the contribution of other small industry types. Both in added value, labor in the number of companies, and in exports, "(Director General of Small and Medium Industries in the opening of the fashion and craft exhibition themed" Indonesia arid Craft 2013 "in Jakarta, Thursday [27/6].

Of the 14 sectors, the added value generated by the fashion and craft sub-sector is quite dominant, respectively $43.02 \%$ and $25.12 \%$ of the total contribution of the creative industry sector.

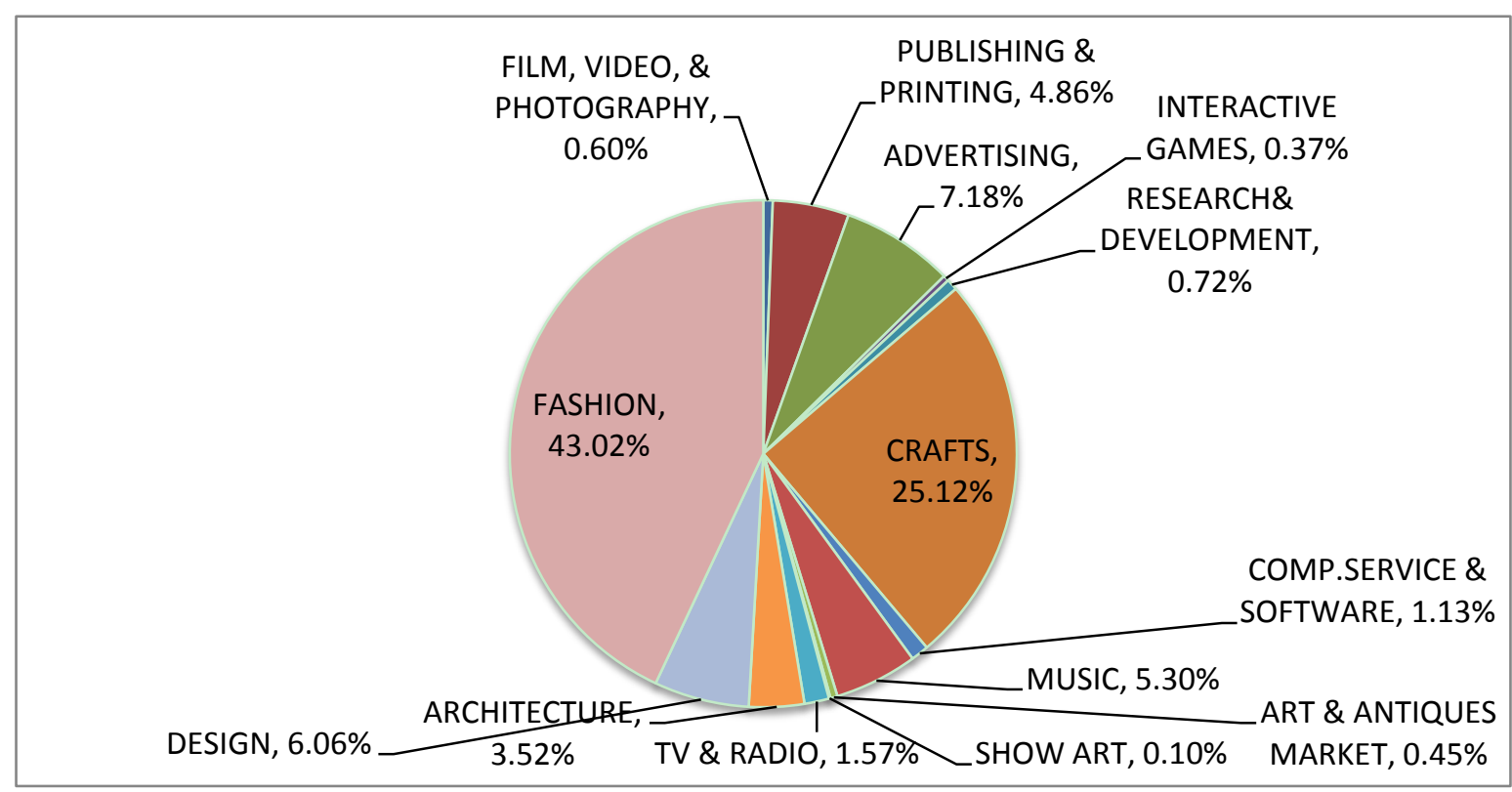

Figure 1. The average percentage of creative industry subsector's contribution to the creative industry (2010-2015)

However, some of the creative industry sub-sectors have very low contribution, namely the sub-sector: Performing arts $(0.10 \%)$; Interactive game $(0.37 \%)$; Markets and art goods $(0.45 \%)$; Film, video, photo graphie $(0.60 \%)$; Research \& development $(0.72 \%)$. Related to the follow up, the preparation of national cooperatives and SMEs to face the MEA era is good enough "So far our Cooperative and SME preparation to face the MEA 2015 era is quite good. One of the main obstacles for the Cooperative and Creative SME (creative industries) sector to compete in the free market era is the quality of human resources (HR) of Cooperatives and SME actors who are generally still low (Minister of Cooperatives and SMEs Syarief Hasan). In relation to the increasingly tight business competition, the creative industry in Indonesia must interpret that organizational competitiveness can be achieved by managing its potential human resources (employees). Human resources can be used as a source of sustainable competitive advantage and not easily replicated by competitors because competitive success gained from effective human resources management is not as transparent as managing other human resources.

A number of parties also considered that until now, the government does not have a comprehensive policy to deal with the AEC that has been running for 1 year. In fact, other countries such as Malaysia, Singapore and Thailand already have specific strategies so that their countries can take optimal advantage in the ASEAN free market.

Entering the AEC in 2017, Indonesia does not seem to have been able to prepare properly related to the improvement of Human Capital (is one component of Intellectual Capital). This can be seen in the Human Development Index (HDI) 2013 indicator, released by UNDP (United Nations Development Program), Transparency International's Corruption Perceptions Index (CPI) 2013 and the Global Competitiveness Index (GCI) 2013-2014 issued by the World Economic Forum (WEF). 
In terms of the strength of human capital, Indonesia is still lagging behind some neighboring countries. Indonesia's HDI figure is still low, which is only 0.62 and in is a group of countries with medium human development index category.

The HDI is still far below Singapore (0.89) and Brunei (0.85) which are able to perform very well in the group of countries with HDI in the very high human development category. Malaysia is also quite far above Indonesia with HDI of 0.76 and belongs to the category of high human development countries (Haseeb, Abidin, Hye \& Hartani, 2018; Aldulaimi \& Abdeldayem 2018).

One approach that is needed by SMEs (including creative industries) in facing business competition is the Intellectual Capital (IC) approach consisting of Human Capital (HC), Structural / Organizational Capital (OC), and Relational / External Capital (EC), and be the main determinant of the success of SMEs (Loureiro and Pedro, 2012).

The reference of Intellectual Capital's role in supporting the performance of creative industries is reinforced by research conducted by Santos Helena et.al (2011) entitled "System of Innovation and innovative SMEs: A Model to Measure the Intellectual Capital of SMEs". The sample in this study was Small and Medium Enterprises (SMEs) totaling 140 SMEs in Spain, with SEM (Structural Equation Model) analysis techniques. Research results show that Human Capital which is an Intellectual Capital dimension is able to contribute to the Commulative Growth Rate of SMEs in Spain. Other research findings by Huang and Hsueh (2007) "A Study on the Relationship Between Intellectual Capital and Business Performance: A Path Analysis". The combination of capability, competence, satisfaction, employee sustainability will create human capital productivity. The research produced Human Capital findings which are the dimensions of Intellectual Capital that are positively related to Business Performance. Similarly, the research by Seleim et al (2007), and F-Jardo'n and Markos (2009). Research by Sharabati, et al (2010), shows that the variables of Intellectual Capital (Intellectual Capital including Human Capital) have a significant and positive influence with Business Performance (BP). Similarly with the research of Chen et al (2004) which states that there is a positive relationship between Intellectual Capital and enterprise performance. Cabrita and Bontis (2007) also stated the same results that each variable of Intellectual Capital (Human Capital, Structural Capital, and Relational Capital) interacts with Business Peerformance.

Regarding the research theme of Intellectual Capital, the research conducted by the research team was conducted by Sukarno (2013) on: The Growth of Fashion Creative Industry Through Human Capital and Institutional Change, the findings produced were that Intellectual Capital (in Human Capital focus) contributed to performance industry. In terms of the strength of human capital, Indonesia is still lagging behind some neighboring countries. The existence of human capital in Indonesia is indeed concerning. This is reflected as follows: Indonesia's HDI figure is still relatively low, which is only 0.62 and is in a group of countries with the medium human development HDI category. The HDI is still far below Singapore (0.89) and Brunei (0.85) which are able to appear very advanced in the group of countries with HDI in the category of very high human development (Sukarno, 2016). In line with this, according to Sukarno and Sawitri (2014) in: The Human Capital And The Institutional Changes of the Trio of Creative Industries ABG In Fashion, the finding produced is Human Capital which has a significant contribution to the performance of the creative industry.

Some of the things that are specific objectives in this study include: This study aims to find out components of intellectual capital those are appropriate for creative industries in East Java. Besides, this research aims to get a real picture of the rules of Human Capital; Structural Capital and Relational Capital creative industries in East Java.

As for the benefits and contribution of the results, it is hoped that new findings can be obtained in relation to intellectual capital (intellectual capital) which includes human capital; structural capital and relational capital (HC, SC, RC) those are applied to creative industries in East Java, so that they can be used to prepare renewable models in the management of creative SMEs that support applied research. Empirically, this research is useful in explaining the role of Intellectual Capital Statement in creative SMEs, namely creative industries in East Java. This research is expected to contribute to the management literature on the development of theories related to the role of human capital, structural capital, and relational capital in evaluating the intellectual capital statement.

\section{Literature Review}

\subsection{Intellectual Capital in Creative Indsutry}

Some authors provide different definitions of intellectual capital. Stewart (1997) defines intellectual capital as intellectual material, namely knowledge, information, intellectual property, experiences used to create prosperity. Steward argued that knowledge has become an important factor of production and therefore intellectual assets must be managed by the company. 
Mouritsen (1998) defines intellectual capital as a technology management process that specializes in calculating future company prospects, while according to Reilly (1992) intellectual capital in the category of intangible assets is something related to technology, consumers, contracts, data processing, personal capital, marketing, location, and goodwill. This definition is still broad and covers almost all dimensions of intangible assets (Jermsittiparsert, 2016; Al-Ahmad \& Ismaiel 2016).

Nick Bontis (1998), states "Intellectual capital is the currency of the new millennium. Intellectual capital (IC) can simply be interpreted as knowledge-based capital owned by the company, which IC is part of intangible assets not only traditional ones (such as brand names, and trademarks), but also new intangible forms (such as knowledge, technology values, and good customer relationships). Company's Intrinsic Value is likened to a tree that produces citrus fruit as a result of a nursery whose products are visible as Financial capital, but there is a value that is no less important in producing citrus fruits, namely supporting roots and fibers as basic values that is not seen which produces values that appear as Intellectual capital. Company assets, sales results and profits are likened to citrus fruits which are Tangible values are Financial capital. While the Intangible value is Intellectual capital, it can be in the form of: human resources, corporate culture, brand, innovation power, technical capabilities, and customer base.

Intellectual capital measurement refers to the dimensions proposed by Edvinsson, and Malone, (1997), Olufemi, (2018), which consists of three main elements, namely: a. Human capital, b. Structural capital, and c. Relational capital (Customer capital)

- Human Capital is the ability of a person who has knowledge and skills in a company, and is able to apply the knowledge and skills possessed at work.

- Structural Capital is the ability of employees in the company to fulfill the processes in it and the structures that support in producing optimal intellectual performance.

- Relational capital is an intangible asset that builds and regulates good relations with customers, employees, governments, stakeholders, and other competitors as well as with partners who can emerge from outside the company.

In Indonesia, so far there have not been many studies on Intellectual Capital (IC) in the creative industry. The importance of IC optimization for Small and Medium Industries is also supported by several studies, including the research of Cohen and Kaimenakis (2007), OLAOYE, ADEDEJI \& AYENI-AGBAJE (2018) which states that IC management contributes positively to the performance of small and medium enterprises (Small and Medium Sized Enterprises or SME's) in Greece. The research of F-Jardon and Martos (2009) on the management of IC in Argentina states that the dimensions of IC, namely structural capital directly affect the performance of SME's wood in Argentina. While other dimensions such as human capital and relational capital indirectly influence through structural capital on the performance of timber companies (SMEs) in Argentina.

Researches related to the theme of Intellectual Capital research have been carried out; one among others is by Sukarno (2013) on: The Growth of Fashion Creative Industry Through Human Capital and Institutional Change, the resulting findings are that Intellectual Capital (in Human Capital focus) contributes to industrial performance. In terms of the strength of human capital, Indonesia is still lagging behind some neighboring countries. The existence of human capital in Indonesia is indeed concerning. This is reflected as follows: Indonesia's HDI figure is still relatively low, which is only 0.62 and is in a group of countries with the medium human development index category. The HDI is still far below Singapore (0.89) and Brunei (0.85) which are able to appear very advanced in the group of countries with HDI in the category of very high human development (Sukarno, 2016; Olowa \& Olowa 2017). In line with this, according to Sukarno and Sawitri (2014) on: The Human Capital and the Institutional Changes of the Trio of Creative Industries ABG in Fashion, the findings produced are Human Capital which has a significant contribution to the performance of the creative industry.

\section{Research Methodology}

\subsection{Research Sites}

The location of this study is in East Java with the city target (dh. Municipality), so that there are 9 cities, namely: Surabaya, Pasuruan, Probolinggo, Malang, Batu, Mojokerto, Kediri, Blitar, and Madiun. Consideration of choosing the area because in reality the creative industry mostly develops in the city of Metropolis, provinces to cities that support creative industry activities that require a lot of information, technology, creativity, innovation.

\subsection{Population and Research Sample}

The population in this study are all sub-sectors (14 sectors) of creative industries in East Java. The sample in this 
study is that the owner / leader / manager of the 5 creative industry sub-sectors that have a very poor contribution (Aktug, Iri \& Top 2018). The sub-sectors are: performing arts; Interactive game; Markets and art goods; Film, video, photo graphie; Research \& development in 9 cities in East Java as many as 45 respondents as samples.

\subsection{Analysis Technique}

The analysis technique in this study uses Descriptive analysis and analysis of Spider Plot Diagrams (radar graphs). Spider plot diagrams are graphical methods displaying multivariate data in the form of two-dimensional graphs of three or more quantitative variables represented by axes starting from the same point. However, because this research is a grant from the Directorate of Research and Community Service of Ministry of Research, Technology, and Higher Education Program in Higher Education Advanced Applied Research which is still in process, the technical analysis used is still using Descriptive analysis techniques.

\section{Research Results and Discussion}

\subsection{Intellectual Capital Description}

Intellectual Capital, the measurement of this variable refers to the dimensions proposed by Edvinsson, and Malone, (1997), which consists of three main elements, namely: a. Human capital, with indicators: Attitude, competencies, education, knowledge, and skills. Whereas dimension: b. Structural capital, with indicators: copyright, corporate culture, desgn rights, financial relations, information technology infrastructure, management processes, service marks, trade secrets, and trademarks. The dimension: c. Customer capital with indicators: brand, company name, customers, distribution channels, franchise agreements, agreements agreements, and loyalty. The complete data can be seen in the following table.

Table 1. Intellectual capital

\begin{tabular}{|c|c|c|c|c|c|c|c|c|c|c|c|c|}
\hline & \multirow[t]{3}{*}{ INDICATOR } & \multicolumn{10}{|c|}{ SCORE } & \multirow{3}{*}{$\begin{array}{l}\text { Mean } \\
\text { (X) }\end{array}$} \\
\hline & & \multicolumn{2}{|c|}{ (1) STS } & \multicolumn{2}{|c|}{ (2) $\mathrm{TS}$} & \multicolumn{2}{|c|}{ (3) $\mathrm{N}$} & \multicolumn{2}{|l|}{ (4) $\mathrm{S}$} & \multicolumn{2}{|c|}{ (5) SS } & \\
\hline & & $\bar{F}$ & $\%$ & $\mathrm{~F}$ & $\%$ & $\mathrm{~F}$ & $\%$ & $\mathrm{~F}$ & $\%$ & $\mathrm{~F}$ & $\%$ & \\
\hline \multirow[t]{2}{*}{ Hc 1} & Attitude & 3 & 1,20 & 0 & 0 & 8 & 3,21 & 148 & 59,43 & 90 & 36,14 & 4.29 \\
\hline & Competencies & 0 & 0 & 3 & 1,20 & 24 & 9,63 & 153 & 61,44 & 69 & 27,71 & 4.16 \\
\hline Hc3 & Education & 0 & 0 & 0 & 0 & 44 & 17,67 & 170 & 68,27 & 35 & 14,05 & 3.96 \\
\hline Hc4 & Knowledge & 21 & 8,43 & 53 & 21,28 & 135 & 54,21 & 19 & 7,63 & 21 & 8,43 & 2.86 \\
\hline \multirow[t]{2}{*}{ Hc5 } & Skills & 0 & 0 & 3 & 1,20 & 31 & 12,44 & 181 & 72,69 & 34 & 13,65 & 3.99 \\
\hline & Subtotal mean & & & & & & & & & & & 3.85 \\
\hline Sc 1 & Copyright & 0 & 0 & 22 & 8,83 & 37 & 14,85 & 153 & 61,44 & 37 & 14,85 & 3.82 \\
\hline Sc 2 & Corporate culture & 0 & 0 & 3 & 1,20 & 16 & 6,42 & 168 & 67,46 & 62 & 24,89 & 4.16 \\
\hline Sc 3 & Design rights & 0 & 0 & 3 & 1,20 & 29 & 11,64 & 182 & 73,09 & 35 & 14,05 & 4.00 \\
\hline Sc 4 & Financialrelations & 7 & 2,81 & 49 & 19,67 & 73 & 29,31 & 85 & 34,13 & 35 & 14,05 & 3.37 \\
\hline Sc 5 & $\begin{array}{l}\text { Information technology } \\
\text { Infrastructure }\end{array}$ & 7 & 2,81 & 24 & 9,60 & 73 & 29,30 & 132 & 53,0 & 13 & 5,20 & 3.48 \\
\hline \multirow[t]{2}{*}{ Sc 6} & Management processes & 0 & 0 & 0 & 0 & 27 & 10,80 & 176 & 70,70 & 46 & 18,50 & 4.08 \\
\hline & Subtotal mean & & & & & & & & & & & 3.81 \\
\hline Rc 1 & Brand & 0 & 0 & 0 & 0 & 16 & 6,40 & 176 & 70,70 & 57 & 22,90 & 4.16 \\
\hline$\overline{\operatorname{Rc} 2}$ & Company name & 0 & 0 & 3 & 1.20 & 63 & 25.30 & 152 & 61.0 & 31 & 12.40 & 3.85 \\
\hline Rc 3 & Customers & 0 & 0 & 0 & 0 & 59 & 23.70 & 151 & 60,60 & 39 & 15.70 & 3.92 \\
\hline $\operatorname{Rc} 4$ & Distribution channels & 0 & 0 & 14 & 5,60 & 77 & 30,90 & 139 & 55,80 & 19 & 7,60 & 3.65 \\
\hline Re 5 & Franchise agreements & 0 & 0 & 0 & 0 & 27 & 10,80 & 180 & 72,30 & 42 & 16,90 & 4.06 \\
\hline \multirow[t]{3}{*}{ Rc 6} & Loyalty & 0 & 0 & 16 & 6,40 & 72 & 28,90 & 153 & 61,40 & 8 & 3,20 & 3.61 \\
\hline & Subtotal mean & & & & & & & & & & & 3.87 \\
\hline & Total mean & & & & & & & & & & & 3.84 \\
\hline
\end{tabular}

Information :

1.STS: strongly disagree; 2 . TS: disagree; 3 . N: Neutral; 4. S: agree; 5. SS: strongly agree

Source: primary data analysis, processed. 
From Table 1 Intellectual capital can be seen that: The largest proportion of opinions seen from the average value is in the $\mathrm{Hc} 1$ indicator "Attitude" with the statement "My employees have a good attitude, are responsive and respond immediately in carrying out their work". This is known from the response to the respondent's answer choice with a mean of 4.29 (Oli, 2018). The proportion of the smallest opinion is seen from the average value found in the HC4 indicator "Knowledge" with the statement "My employees have extensive knowledge and insight in carrying out their work" with a mean of 2.86 (Ale, Akter \& Islam 2018).

As for when viewed from the strength of Intellectual capital in each dimension of human capital, structural capital, and relational capital, it appears in the Relational capital dimension with the mean sub-value of 3.87 with the meaning that the implementation of intellectual capital in the creative industry is more prominent in the Relational capital component that is in a strong range. Whereas if viewed from the strength of intellectual capital as a whole (Total), it can be seen from the mean value of 3.84 which has the meaning that intellectual capital in the creative industry is in a strong range (Olaoye \& Olanipekun 2018).

Thus it can be concluded that the existing intellectual capital in the creative industry is strong and prioritizes the Relational capital dimension.

\subsection{Description of Creative Industry Performance}

Creative Industry Performance, measurement of this variable refers to several references that need to be adjusted (Shepherd (2004), Bontis (1998), Swamidass and Newell, (1987), Ministry of Trade of Indonesia (2008) consisting of: a. employment opportunities, b. profit level, c. industrial growth, d. profit growth, e. sales growth, f. overall response to competition, g. level of success in new product launches, h. creativity escalation, i. skill escalation, $\mathrm{j}$. individual talent escalation. The full data can be seen in the following table.

From the following table of creative industry performance can be seen that: The largest proportion of opinions seen from the mean value is found in indicator Kik 5 "Growth in market share" with the statement "My business has a growing market share that increases over time". This is known from the response to the respondent's answer choice with a mean of 3.8554. Whereas seen from the proportion of the smallest opinion found in the Kik 4 indicator "Employment Opportunities" with the statement "My business, has employment opportunities for new employees" This implies that the performance of the creative industry places more emphasis on market share growth in the high range.

Table 2. Description of creative industry performance

\begin{tabular}{|c|c|c|c|c|c|c|c|c|c|c|c|c|}
\hline & \multirow[t]{3}{*}{ INDICATOR } & \multicolumn{10}{|c|}{ SKOR } & \multirow[t]{3}{*}{ Mean $(\mathrm{X})$} \\
\hline & & \multicolumn{2}{|c|}{ (1) STS } & \multicolumn{2}{|c|}{ (2) TS } & \multicolumn{2}{|c|}{ (3) $\mathrm{N}$} & \multicolumn{2}{|c|}{ (4) $\mathrm{S}$} & \multicolumn{2}{|c|}{ (5) $\mathrm{SS}$} & \\
\hline & & $\overline{\mathrm{F}}$ & $\%$ & $\mathrm{~F}$ & $\%$ & $\mathrm{~F}$ & $\%$ & $\mathrm{~F}$ & $\%$ & $\mathrm{~F}$ & $\%$ & \\
\hline Kik 1 & Provit growth & 0 & 0 & 14 & 5.60 & 65 & 26,10 & 142 & 57,0 & 28 & 11,2 & 3.74 \\
\hline Kik 2 & Sales growth & 0 & 0 & 11 & 4.40 & 63 & 25,30 & 160 & 64.30 & 15 & 6,0 & 3.72 \\
\hline$\overline{\text { Kik } 3}$ & $\begin{array}{l}\text { level of success in new produc } \\
\text { launches }\end{array}$ & & 0 & 11 & 4,40 & 67 & 26.9 & 147 & 59.0 & 24 & 9,60 & 3.74 \\
\hline$\overline{\text { Kik } 4}$ & Employment opportunuties & 0 & 0 & 20 & 8.0 & 57 & 22,90 & 149 & 59.80 & 23 & 9.20 & 3.70 \\
\hline Kik 5 & Market growth & 0 & 0 & 19 & 7.60 & 35 & 14.10 & 158 & 63.50 & 37 & 14.9 & 3.86 \\
\hline & Total mean & & & & & & & & & & & 3.75 \\
\hline
\end{tabular}

Information:

1.STS: strongly disagree; 2 . TS: disagree; 3 . N: Neutral; 4. S: agree; 5 . SS: strongly agree

Source: primary data analysis, processed

As for when viewed from the high and low performance of the creative industry on the description table above, it can be seen from the total mean value of the mean $=3.75$ with the meaning that the performance of the creative industry in East Java has a high range. Thus it can be concluded that the performance of the creative industry has a high range and emphasizes more on the "growth of market share" of the creative industry. 


\section{Conclusion}

Intellectual Capital in the creative industry in the performing arts sub-sector; Interactive game; Markets and art goods; Film, video, photo graphie; Research \& development has different mapping in each dimension. The Relational Capital Dimension has more prominent mapping than Structuraal capital or Relational capital. The Human Capital dimension of the Hc1 indicator "Attitude" is the most dominant indicator. As you can see, the lowest indicator is on the Hc4 indicator "Knowledge". While the Kik 5 indicator is the most dominant indicator. In line with this, the indicator Kik 4 is the lowest indicator.

\section{Grateful Expression}

Thank you to the Head of the East Java Provincial Office of Industry and Trade. The gratitude is also expressed to the Chair of the Arts Council in East Java: Surabaya, Mojokerto, Batu, Malang, Pasuruan, Probolinggo, Kediri, Blitar, and Madiun. Last but not least, the gratitutd also goest to the manager / leader / owner of creative industry sub-sector: performing arts; interactive game; markets and art goods; film, video, photo graphie; research \& development.

\section{References}

Ahmed, U., Khalid, N., Ammar, A., \& Shah, M. H. (2017). Assessing moderation of employee engagement on the relationship between work discretion, job clarity and business performance in the banking sector of Pakistan. Asian Economic and Financial Review, $1197-121$. https://doi.org/10.18488/journal.aefr.2017.712.1197.1210

Aktug, Z. B., Iri, R., \& Top, E. (2018). The Investigation of the Relationship between Children's 50m Freestyle Swimming Performances and Motor Performances. Asian Journal of Education and Training, 4(1), 41-44. https://doi.org/10.20448/journal.522.2018.41.41.44

Al-Ahmad, Z., \& Ismaiel, L. (2016). Testing the PPP Using Unit Root Tests with Structural Breaks: Evidence from Politically Unstable Arab Countries. International Journal of Business, Economics and Management, 3(12), 173-187. https://doi.org/10.18488/journal.62/2016.3.12/62.3.173.187

Aldulaimi, S. H., \& Abdeldayem, M. M. (2018). The Economic Value of Time in Arab Culture: New Evidence using Zimbardo Time Perspective Inventory (ZTPI). American Journal of Social Sciences and Humanities, 3(1), 63-72. https://doi.org/10.20448/801.31.63.72

Ale, S. A., Akter, R., \& Islam, M. S. (2018). Remittance Inflow and GDP Growth: Evidence from Bangladesh, India and Pakistan. Asian Economic and Financial Review, 8(11), 1340-1353. https://doi.org/10.18488/journal.aefr.2018.811.1340.1353

Cabrita, M. D. R., \& Bontis, N. (2008). Intellectual Capital and Business Performance in The Portuguese Banking Industry. Int. J. Technology Management, 43(1-3), 212-237. https://doi.org/10.1504/IJTM.2008.019416

Chen, et al. (2005). An Empirical Investigation of The Relationship Between Intellectual Capital and Firm's Market Value and Financial Performance. https://doi.org/10.1108/14691930510592771

DCMS \& Creative Industries Task Force. (1998). Creative Industries 1998: Mapping Documents. London: UK Department for Culture, Media and Sport.

Departemen Perdagangan Republik Indonesia. (2008). Pengembangan Ekonomi Kreatif Indonesia 2025: Rencana Pengembangan Ekonomi Kreatif Indonesia 2009-2025.

Dorrego, L. D. P. F. (2012). Intellectual capital and system of innovation: What really matters at innovative SMEs. Intellectual Capital, 8(2), 239-274. https://doi.org/10.3926/ic.273

Fitriyah, M. A. T. (2015). Model Pengembangan keuangan Inklusif Pada Sentra Usaha kecil Menengah Di Jawa Timur. Hasil Penelitian.

Haseeb, M., Abidin, I. S. Z., Hye, Q. M. A., \& Hartani, N. H. (2018). The Impact of Renewable Energy on Economic Well-Being of Malaysia: Fresh Evidence from Auto Regressive Distributed Lag Bound Testing Approach. International Journal of Energy Economics and Policy, 9(1), 269-275.

Huang, Y., \& Wu, Y. J. (2010). Intellectual Capital and Knowledge Productivity: the Taiwan Biotech Industry. Management Decision, 48(4), 580-99. https://doi.org/10.1108/00251741011041364

InCas. (2008). Intellectual Capital Statement Made In Europe. Retrieved from http: //www.incas-europe.org

Irbayuni, S. (2015). Model Strategi Pemasaran Kerajinan Mebel di Kabupaten Pasuruan Jawa Timur (tahun 1). Hasil Penelitian PUPERTI. 
Irbayuni, S. (2016). Model Insentif Investasi dan Penguatan Kelembagaan di Kabupaten Ngawi Jawa Timur. Hasil Penelitian Hibah Bersaing.

Jermsittiparsert, K. (2016). Culture of 'Elephant front legs-hind legs': A debate on the actuality of sexual politics in Thai society. The Social Sciences, 11(1), 20-28.

Mouritsen, J. (1998). Driving Growth: Economic Value Added versus Intellectual Capital. Management Accounting Research, 9, 461-482. https://doi.org/10.1006/mare.1998.0090

Olaoye, C. O., \& Olanipekun, C. T. (2018). Impact of Forensic Accounting and Investigation on Corporate Governance in Ekiti State. Journal of Accounting, Business and Finance Research, 4(1), 28-36. https://doi.org/10.20448/2002.41.28.36

Olaoye, C. O., Adedeji, A. Q., \& Ayeni-Agbaje, R. A. (2018). Commercial Bank Lending to Small and Medium Scale Enterprises and Nigeria Economy. Journal of Accounting, Business and Finance Research, 4(2), 49-55. https://doi.org/10.20448/2002.42.49.55

Oli, S. K. (2018). Impact of Microfinance Institutions on Economic Growth of Nepal. Asian Journal of Economic Modelling, 6(2), 98-109. https://doi.org/10.18488/journal.8.2018.62.98.109

Olowa, O. A., \& Olowa, O. W. (2017). Rice Farmer and Capital Formation: A Case Study of Rice Farmer's Credit Cooperative in Itoikin, Ikosi-Ejirin LCDA, Lagos State. International Journal of Sustainable Development \& World Policy, 6(1), 1-8. https://doi.org/10.18488/journal.26.2017.61.1.8

Olufemi, A. S. (2018). Measuring and Assessing the State of Technological Innovations and the Level of Interaction between Rice Processors and Stakeholders in Rice Processing Industry in Nigeria. International Journal of Business, Economics and Management, 5(6), 164-175. https://doi.org/10.18488/journal.62.2018.56.164.175

Purwanto, A. B. (2015, June). Pengaruh Service Performance Dan Relationship Marketing Terhadap Loyalitas Konsumen. Fokus Ekonomi: Jurnal Ilmiah Ekonomi,10(1).

Reilly, R. (1992). Interstate Intangible Asset Transfer Program. CPA Journal, 62(8), 34-40

Santos-Rodrigues, H., Gonzalez-Loureiro, M., \& Figueroa-Dorrego, P. (2012). System of Innovation and innovative SMEs: A Model to Measure the Intellectual Capital of SMEs. Proceedings of the 4th European Conference on Intellectual Capital.

Sawitri, S. D. (2014). Dalam: The Human CapitalAndThe Institutional Changes of Trio ABG in Fashion Creative Industries.

Stewart, T. A. (1997). Intellectual Capital: The New Wealth of Organisations. Doubleday-Currency, London.

Sukarno, G. (2013, September 18-20). Menumbuhkan Industri Kreatif Di Surabaya, Seminar Nasional \& Sidang Pleno ISEI XVI "Mempercepat Penguatan Daya Saingekonomi Daerah Menghadapi Masyarakat Ekonomi Asean 2015”. Abadi Suite Hotel Jambi.

Sukarno, G. (2014, October 28). Pertumbuhan Industri Kreatif Fesyen Melalui Human Capital Dan Perubahan Institusi, Call for Paper Bank Indonesia 1st East Java Economic Forum 2014 (EJAVEC). Mendorong Transformasi Ekonomi Jawa Timur Menuju Masyarakat Mandiri dan Dinamis, Universitas Airlangga.

Sukarno, G. D. W., \& Wulan, R. (2012, August). Competitive Advantage Through "SANTRI" Community In Improving Performanve. Global Network International, Journal of Business Management, 2(5).

Sukarno, G., \& Dan Nirawati, L. (2013). Model Community Development Dalam Pola Corporate Social Responsibility Untuk Meningkatkan Kinerja UKM, Hasil Penelitian (SKIM Hibah Bersaing, DIPA Kemdikbud Kopertis Wil VII). 